\title{
Um Século de Cólera: Itinerário do Medo
}

\author{
LUIZ ANTONIO DE CASTRO SANTOS *
}

I

A cólera não teve início na Europa, mas sim na Ásia, daí ser chamada de "cólera asiática" pelos epidemiólogos. Surpreendentemente, a historiografia sobre esta doença temível, causada pelo bacilo Vibrio comma, dá maior destaque a seus efeitos sobre as populações européias do que sobre as asiáticas.

A ênfase no itinerário europeu da doença deve-se em grande parte a seu caráter epidêmico. Acrescente-se a isto o ingrediente político e social a que esteve freqüentemente associada a chegada da cólera nos países europeus crises políticas e agitaçōes populares contra os governos em razāo das medidas de controle sanitário e sua ineficácia - e se compreenderá o destaque concedido pelos historiadores ao itinerário europeu do bacilo. Na Ásia teríamos a configuração de uma endemia, não de uma epidemia, termo que sugere maior gravidade do que o primeiro. Por que então "endemia" na Ásia, se o flagelo naquela região foi sempre gravíssimo? Há uma ironia perversa na resposta: os especialistas consideram o termo endemia apropriado para doenças que provocam, em média, um número estável de vítimas em certa região ou país durante muitos anos (por exemplo, dez anos ou mais). Assim, o contato de alguns séculos entre o microorganismo e as populações asiáticas, ainda que responsável por altíssimos índices de mortalidade - que perduram até os nossos dias, sobretudo na Índia -, configura uma situação endêmica, pois esses índices têm sido estáveis durante um longo período. O earáter endêmico da doença expli-

* Professor adjunto do Departamento de Ciências Humanas e Saúde do IMS/UERJ e pesquisador licenciado do Cebrap. 
caria, por sua vez, a tolerância dos governos daqueles países em relação à cólera e a ausência de revoltas populares contra o descaso governamental.

Tem-se notícia da primeira aparição epidêmica na Europa em fins do século XII ou início do XIII. Nessa época, entretanto, outras doenças castigavam mais duramente o continente, como a lepra e a varíola. A Peste Negra seria o grande mal do século seguinte. O período de cerca de 300 anos, a partir de 1200 até os Descobrimentos, caracterizou-se pela primeira grande penetração de doenças da Ásia na Europa, atribuída por historiadores como William McNeill ao impacto dos movimentos populacionais e comerciais provocado pelo Império Mongol. Os governos imperiais mongólicos, implantados por Genghis Khan, chegaram a controlar todo o território chinês e quase toda a Rússia, bem como a Ásia Central, o Irã e o Iraque. A peregrinação do bacilo da peste bubônica (Pasteurella pestis), a partir dos focos primitivos no sudoeste da China e na Birmânia, fez-se através das rotas de caravanas pela Ásia até a Criméia e dali espalhou-se por toda a Europa a partir dos portos do Mediterrâneo. ${ }^{1}$

Ainda que a cólera tenha feito suas primeiras vítimas nessa época de ampliação dos contatos entre Europa e Oriente, foi no século XIX que ela marcou profundamente a história da humanidade, originando-se dos seus nichos ecológicos na Índia - um permanente foco de reprodução do bacilo ainda em nossos dias - e propagando-se da região de Bengala e do Delta do Ganges por toda a Europa e Américas.

A historiografia sobre as grandes epidemias - é William McNeill quem defende este argumento — raramente as examina como instâncias de rupturas epidemiológicas, que são rompimentos violentos no equilíbrio biológico entre microorganismos ou "microparasitas" e hospedeiros humanos. ${ }^{2}$ Tais rupturas provocam sempre choques violentos nas estruturas sociais, econômicas, culturais, políticas e demográficas. Por vezes, decorrem da própria ausência de mudanças sociais e, neste caso, poderiam ser consideradas um efeito indireto da rigidez das sociedades humanas. A Peste Negra, que se abateu sobre as populações juntamente com a Grande Fome do século XIV, é um exemplo de ruptura epidemiológica, na conceituação de McNeill. A

1. Veja-se o clássico de W. H. McNeill, Plagues and Peoples, Garden City, Nova Iorque, Anchor Books, 1976, cap. IV.

2. Idem, "Introduction". Quando um organismo infeccioso, como o Vibrio comma, mata seu hospedeiro, cria de certo modo uma crise para si próprio, pois um novo hospedeiro terá de ser encontrado para que a cadeia geracional do microorganismo prossiga. Em termos bem simples, esse desajuste é um exemplo de ruptura ecológica, que, quando atinge e elimina grande número de hospedeiros, passa a configurar uma ruptura epidemiológica. Este foi o fenômeno que se verificou com a cólera no século XIX. 
cólera representa também um exemplo histórico clássico: esse "flagelo brutal e espetacular” do século XIX obedeceu ao padrão de difusão e circulação de doenças transmissíveis através do mundo, tendo se expandido ainda mais pelo-globo do que a Peste Negra na Idade Média. ${ }^{3}$

\section{A cólera e a Europa no século XIX}

A Europa do século XIX passou por uma enorme onda de crescimento populacional, fruto da redução dos níveis de mortalidade. Em grande parte, isto se deveu ao controle da varíola, que já se iniciara desde o século XVIII pela prática mais primitiva da inoculação, mas se difundira efetivamente apenas no século seguinte, com a imunização pela vacina jenneriana. Desde as Guerras Napoleônicas, os exércitos - grandes propagadores das cadeias infecciosas sempre que invadiam populaçōes até então não expostas a determinadas doenças - passaram a ser imunizados para impedir perdas nas próprias fileiras, que congregavam soldados de diferentes regiōes de um mesmo país.

A cólera, apesar de provocar alguns surtos de mortalidade, não chegou a interromper o ritmo de crescimento populacional europeu. O século da cólera foi também o século da intensificação dos contatos entre o Velho Mundo e o Novo, em funçāo do desenvolvimento dos transportes terrestres e marítimos. Foi, ainda, um tempo de avanços do microparasitismo e dos esforços administrativos para contê-lo, tanto no campo sanitário como no da chamada polícia médica - esta, uma espécie de instrumento da incipiente organização dos serviços sanitários para atuar junto à população no combate à cólera e outras "pestilências". Além disso, foi esse o século das primeiras medidas sanitárias internacionais contra a expansão de doenças como a cólera e a varíola.

Todos esses esforços esbarravam em um grande obstáculo à produção de efeitos duradouros: as limitações do saber médico. Sabe-se que até por volta de 1880 - década que marca o início da era bacteriológica —, o progresso médico apoiava-se em doutrinas errôneas sobre a propagação das infecções. Desde os tempos de Hipócrates (séc.V a.C.), uma corrente da medicina acreditava que as doenças eram causadas por miasmas, emanações exaladas por águas estagnadas, cadáveres ou qualquer outra matéria em decomposição. Em contato com miasmas, pessoas suscetíveis ou enfraquecidas acabavam por cair doentes. Houve mais tarde uma teoria alternativa: era a chamada teoria do

3. Ibidem. Ver, também, P. Bordelais, "Le Choléra: Présentation”, in J.P. Bardet et alli, Peurs et Terreurs face à la Contagion, Paris, Fayard, 1988. 
germe, uma doutrina "contagionista" por excelência. Defendida desde o século dos Descobrimentos pelo italiano Girolamo Fracastoro, a doutrina tornou-se mais aceita do que a teoria miasmática até fins do século XVIII e deu ensejo às medidas sanitárias do isolamento de indivíduos e animais doentes, bem como da quarentena de pessoas a bordo de navios ou em lazaretos.

Porém, essas medidas foram duramente combatidas e chegaram a cair em desuso nos primeiros tempos da cólera. Em 1822, médicos franceses que pesquisavam as causas de um surto de febre amarela em Barcelona concluíram pela impossibilidade de contágio direto entre as pessoas infectadas. $O$ xeque-mate aos contagionistas veio ao encontro do pensamento liberal, que via nas medidas de quarentena um embaraço ao livre comércio e no isolamento das pessoas uma transgressão aos direitos civis. Como não havia ainda bases científicas para que se aventasse a ação de insetos e da água como possíveis transmissores de germes - nos exemplos clássicos da febre amarela e da cólera - as medidas de quarentena e isolamento foram duramente combatidas e os miasmas ganharam novamente um lugar cativo no pensamento médico da época. ${ }^{4}$

Mas a partir de 1850 a cólera começou a reverter a balança do saber médico em direção às teorias do contágio por germes. O primeiro sinal da mudança surgiu de um verdadeiro trabalho de "médico-detetive" feito pelo inglês John Snow. ${ }^{5}$ Trabalhando como se estivesse conduzindo um experimento, por tentativa e erro, o médico inglês conseguiu descobrir que um surto violento no centro da cidade de Londres, que chegou a vitimar 500 pessoas entre 31 de agosto e 10 de setembro de 1854, provinha de uma bomba d'água contaminada usada pela populaçäo local. Snow propunha-se, ainda, a demonstrar que as evacuaçōes de um doente, ao atingirem as águas da cidade, podiam disseminar o "veneno mórbido" para a população que fizesse uso dessas águas. Não eram eflúvios e exalaçōes pútridas os causadores da doença, dizia ele, mas sim os germes contidos na água usada para beber. Snow nāo identificara o bacilo causador - que o médico e pesquisador alemão Robert Koch descobriria décadas mais tarde -, mas suas conclusões sobre a forma indireta de contágio punham em dúvida a validade da teoria miasmática. ${ }^{6} \mathrm{~A}$ ciência médica de toda

4. A discussāo sobre as doutrinas epidemiológicas está em W. H. McNeill, Plagues and., op. cit., cap. Vl.

5. Confrontar a ótima matéria de C. Csillag, "Médico-Detetive Desvendou Transmissāo do Cólera", Folha de S.Paulo, Caderno 7, 15/3/1991, p. 2.

6. Veja-se a descriçāo pioneira de suas teorias - divulgadas em 1849 , antes portanto de suas descobertas em Londres - no livro clássico de Snow, traduzido recentemente para o português: J. Snow, Sobre a Maneira de Transmissão do Cólera (Traduçāo realizada pela USAID, revisada), São Paulo, Hucitec, 1991. 
a Europa ainda tardaria algumas décadas para aceitar definitivamente a explicação do contágio pelos germes. Foram as pesquisas de Pasteur e Koch que inauguraram a era bacteriológica, no fim do século XIX.

\section{O itinerário da pandemia}

A historiografia refere-se à peregrinação global para descrever o vasto movimento do flagelo durante o século XIX, infestando e infectando populações em vários continentes. Um novo padrão de circulação de doenças se inaugurava por força dos deslocamentos dos povos no Velho Mundo e entre o Velho e o Novo Mundos, tudo isso, por sua vez, provocado pelo crescimento industrial e pelos processos de colonização e imperialismo.

De início, a cólera extravasou os limites do subcontinente indiano - a partir de 1817 - em razão das manobras militares e das novas rotas de comércio dos ingleses. Naquele ano se iniciava a primeira pandemia (rigorosamente, uma epidemia generalizada) do mundo moderno.

Acompanhar o trajeto formidável do bacilo lançando mão de um mapamúndi, lembra de certo modo uma aula de geopolítica: o poder britânico espalhando pelos mares interiores e oceânicos o vibrião colérico. As tripulaçōes dos navios conduziram o bacilo, inicialmente, do fundo do Golfo de Bengala para sudoeste, em direção à Indonésia e à Indochina, e daí para o norte, alcançando a China e o Japão em 1822. Outro percurso tomou a doença através do Mar da Arábia até a localidade de Mascate, na entrada do Golfo Pérsico. Uma força expedicionária inglesa chegou àquela cidade em 1821, com o objetivo de estancar o tráfico de escravos. Logrou infectar a região com a cólera, de onde se propagou, ao sul, para o continente africano, pelas vias do tráfico, e a noroeste, até atingir o Iraque, o Irã, a Síria, a Turquia e a Rússia, através do Mar Cáspio.?

Uma segunda pandemia grassou a partir de 1830. Originando-se novamente do Delta do Ganges, a doença refez seu trajeto em direção ao sul deste país. As campanhas militares deste país projetaram o vibrião para o interior da Polônia. O transporte marítimo pelo Báltico e pelo Mar do Norte foi responsável pela invasão da Inglaterra pelo bacilo. Em 1832, a epidemia alastrou-se para a Irlanda, de onde as correntes migratórias da população rumo à América do Norte lograram realizar também a emigração do bacilo. Assim se efetivava, pela primeira vez na história, a transmigração do

7. Esta discussāo se baseia em W. H. McNeill, Plagues and..., op. cit., pp.231-3. 
cólera-morbo para o continente americano. Ainda em 1832 a epidemia estendeu-se do Canadá para os Estados Unidos, e dali prosseguiu sua rota do sul em direção ao México (1833). A epidemia generalizara-se para todo o globo: a década de 1830 marcou a definitiva globalização da pandemia.

A estabilização ou equilíbrio da doença — que passava a ser endêmica entre as populações atingidas - devia-se à ineficácia de medidas sanitárias, que, como se saberia mais tarde (a partir da revolução bacteriana do fim do século), só se tornariam eficazes pela descontaminação da água e pela canalização dos esgotos. Passado algum tempo da acomodação biológica entre o microorganismo e seu hospedeiro, que ocorria depois de grandes mortandades, novas pandemias recrudesceram na Ásia e refizeram-se as antigas rotas e o itinerário do pânico entre as populações. A partir de 1850 , a navegação a vapor e o transporte ferroviário intensificaram os deslocamentos populacionais e as trocas comerciais. Das antigas rotas brotavam outros cursos da doença. $O$ Brasil não tardaria a incluir-se nos novos itinerários.

Médicos de nomeada no Brasil, como José Pereira Rego, acreditavam que o calor - a proximidade do Equador - defenderia as cidades da infestação pela cólera. Ironicamente, a argumentação lembrava a crença corrente à época dos Descobrimentos, segundo a qual os bons ares, o "saudável temperamento da terra", seriam a garantia de imunidade contra as pestilências que grassavam ao norte do Equador. ${ }^{8}$ As esperanças de imunidade se desfizeram em poucos anos. Em 1855, os portos brasileiros já acusavam os primeiros casos de infecção colérica. ${ }^{9}$ (Ver discussão adiante sobre o Brasil.)

\section{O combate: organização sanitária e métodos}

Fosse pela doutrina dos miasmas - que requeria a drenagem dos pântanos e a remoção das matérias apodrecidas para o combate às enfermidades - , fosse pela teoria do contágio - que exigia o isolamento dos enfermos e a quarentena,

8. Para uma análise das crenças sobre a ausência de padecimentos físicos e a longevidade dos habitantes do Novo Mundo, ver S. B. de Holanda, Visão do Paraíso ( $4^{a}$ ed.), São Paulo, Ed. Nacional, 1985. “A certeza, alcançada já quase ao início dos grandes descobrimentos marítimos, se não antes, de que as pestilências de bordo prontamente desapareciam ao contato de certas terras privilegiadas” (p. 269).

9. Os primeiros casos foram diagnosticados em Belém do Pará, em maio de 1855. Nâo há dados definitivos sobre a fonte transmissora, mas a chegada de um navio de Portugal com prováveis vítimas de cólera, em maio, teria causado a primeira irrupçảo do flagelo asiático em território brasileiro. Ver D. B. Cooper, "The New 'Black Death': Cholera in Brazil, 1855-1856", Social Science History, vol. 10, $\mathrm{n}^{\circ} 4,1986$, p. 239. 
além das medidas de saneamento e cuidados com a água potável preconizados por John Snow -, o certo é que a luta contra a cólera veio a gerar uma preocupação, da parte dos governos locais, com a saúde e o saneamento.

Uma questão básica com que se defrontaram tais governos foi a falta de instrumentos de ação, não apenas de métodos de ação. Ou seja, não bastava que se preconizasse a remoção do lixo ou o isolamento dos enfermos. Persistia uma questão até então não resolvida: como colocar em prática tais medidas? Como estabelecer as normas e como fiscalizar sua éxecução? A cólera foi, em boa parte, responsável pelas primeiras iniciativas da organização sanitária, em resposta a tais problemas. As Juntas de Higiene nacionais, como no Brasil, eram pouco eficazes e deram lugar a aparatos administrativos de saúde - ainda que toscos — de âmbito local ou regional. Já onde havia conselhos locais de saúde, nāo raro se tornaram mais ativos e, ao se multiplicarem, acabaram por exigir a criação de organismos de alcance nacional (quase sempre de curta duração, como na Inglaterra).

Na Inglaterra. A eclosão da primeira epidemia de cólera, em 1832, foi decisiva para a instalação de Juntas locais de higiene na Inglaterra. $O$ pavor que afligiu a população, diante do mal asiático, pressionou o Parlamento a agir, até que a violência do flagelo se reduzisse a proporções endêmicas. ${ }^{10}$ Quando uma nova pandemia mundial atingiu o território inglês, dessa feita os reformadores sociais britânicos foram além de soluções locais, e criaram a Junta Central de Higiene, em 1848. Dirigida por reformadores como Sir Edwin Chadwick, autor, em 1842, de um monumental estudo sobre as condições sanitárias da população operária da Grã-Bretanha, a Junta procurou limpar as cidades inglesas e instalar novos sistemas de distribuição de águas e esgotos em todo o país. Chadwick havia desenvolvido um novo sistema de esgotos, de canos de cerâmica, que desaguariam em depósitos distantes dos aglomerados urbanos. O Plano Chadwick exigia sistemas novos de água e esgotos e a eliminação compulsória dos antigos. As resistências da população não foram poucas, pois o Plano feria os direitos dos particulares, na medida em que, por exemplo, os canos em linha reta atravessassem propriedades privadas. A Junta Central teve curta duração (1848/1854), mas antecipou o cenário das novas cidades saneadas da era industrial.

No Brasil. A primeira cidade atingida pelo cólera-morbo foi Belém, em 26 de maio de 1855 , quando os primeiros dois casos foram diagnosticados por um

10. W. H. McNeill, Plagues and..., op. cit., pp. 240 e ss. 
jovem médico formado pela Faculdade da Bahia. Na Junta Central de Higiene Pública (criada em 1850 em reação à entrada da febre amarela no País em 1849), tanto quanto nas poucas Juntas existentes nas Províncias, predominavam os anticontagionistas.

Nesse contexto, não seria difícil prever que, entre as ações de controle sanitário propostas por uma comissão médica especialmente criada pelo governo do Pará, näo constava a quarentena da tripulação de um navio português aportado em Belém, da qual se sabia ter sofrido um surto mortal de cólera durante a viagem. Tão grave quanto o descaso em relação a esse foco de importação da doença foi a permissão das autoridades para que o navio prosseguisse viagem para o sul do País. Não tardou para que outras cidades costeiras fossem atingidas: em julho, Salvador, Bahia, foi acometida. Em poucos meses a doença começou a gravitar entre os portos de Salvador e o norte do País: em 1856 a epidemia já alcançara as Províncias de Sergipe, Alagoas, Rio Grande do Norte, Paraíba e Pernambuco.

O Rio de Janeiro foi, depois de Belém e Salvador, o foco mais importante de importação do cólera-morbo. Os primeiros casos foram registrados ao mesmo tempo em que as primeiras vítimas apareciam em Salvador: julho de 1855. No Rio, o presidente da Junta Central de Higiene Pública, professor Francisco de Paula Cândido, viu-se forçado a preconizar medidas de quarentena - ainda que duvidasse da ação do contágio -, mas o grande movimento de navios no porto acabou por comprometer o cordão sanitário precariamente implantado em volta da cidade. As províncias mineira e paulista foram poupadas do flagelo, que parecia esmaecer longe das áreas litorâneas. $\mathrm{O}$ porto paulista de Santos, entretanto, estava fadado à invasāo da moléstia, ainda que ali ela nảo tenha se abatido com gravidade.

A cólera elegeu Porto Alegre como o ponto extremo de devastação ao sul, em novembro de 1855. ${ }^{11}$ Atribuiu-se a origem do foco à entrada no porto de um navio que já disseminara a doença em Santa Catarina. Uma quarentena foi imposta ao navio, mas alguns passageiros se evadiram, burlando o controle sanitário. ${ }^{12}$

11. Ao norte, a Província do Amazonas chegou a contar alguns casos da doença, com baixa letalidade, no ano de 1856. O pequeno foco foi causado, em Manaus e em algumas localidades à beira do Amazonas, por tripulantes doentes trazidos por vapores de Belém. Ver R. Braga, "Cólera no Amazonas", Leitura, vol. 10, n 119, Sāo Paulo, Imprensa Oficial do Arquivo do Estado, abril de 1992, p. 10.

12. Esses dados sobre a collera no Brasil constam do importante artigo de D. B. Cooper, "The New 'Black...”, op. cit. 
A devastação e o terror causados pela cólera junto à população brasileira — mais precisamente, nas cidades litorâneas onde o mal se abateu — foram responsáveis pela atuaçāo mais destacada, mas nem sempre através de métodos adequados, das Juntas central e provinciais de higiene, bem como das autoridades sanitárias locais, em Conselhos de salubridade pública como o da cidade de Salvador.

À semelhança da reação inglesa ao flagelo, as autoridades brasileiras nāo ficaram adstritas a iniciativas de polícia médica — proibição de sepultamento nas igrejas, instruções aos médicos sobre sintomas e tratamento do mal, estabelecimento de enfermarias de emergência e, mais raramente, adoção de quarentenas ${ }^{13}$-, mas deram atenção ao que hoje chamaríamos de saneamento básico das cidades litorâneas. No tocante ao tratamento da doença é que residiam os maiores problemas, pois, em sintonia com o saber médico da época, preconizavam-se terapêuticas ineficazes, como friç̧ões de álcool canforado, suadouros e gotas de láudano. No tocante às obras de saneamento, medidas efetivas, como a instalação de redes de esgoto e sistemas de encanamento d'água, a partir de 1862, em algumas cidades litorâneas como o Rio de Janeiro, Recife e Santos, foram a resposta, com algum atraso, à invasão da cólera (bem como da febre amarela). A companhia City Improvements, formada em 1862, em Londres, mediante contrato para a execução no Rio de Janeiro de um sistema de esgotos, baseou-se na experiência recente de saneamento de cidades inglesas. Esta experiência foi seguida em outros centros atingidos pela cólera, como Santos e Recife, já na década de $1870 .{ }^{14} \mathrm{Um}$ novo sistema de abastecimento domiciliar de água foi inaugurado no Rio de Janeiro mais tarde, em 1880 , pela administração pública. ${ }^{15}$

13. Veja-se L. Santos Filho, História Geral da Medicina Brasileira, vol. 2, São Paulo, Hucitec/Edusp, 1991, pp. 208-14.

14. Note-se que na capital paulista a Companhia Cantareira de Águas e Esgotos (tambem inglesa) só completou um sistema modesto, que atendia a uma pequena parte da populaçáo, em 1885. É difícil associar a implantação tardia do saneamento em Sảo Paulo — em relaçăo às cidades portuárias - apenas à ausência de epidemias do cólera-morbo naquela cidade. Entretanto, um sinal importante do impacto sempre considerável causado pelo flagelo asiático é que, finalmente atingida pela cólera na década de 1890 , seguiu-se a expansăo da rede de esgotos e de abastecimento d'água em São Paulo durante a curta administraçăo de Rodrigues Alves à frente do governo paulista (1900/1902). Ver J. L. Love, Säo Paulo in the Brazilian Federation, 1889-1937, Stanford, Stanford University Press, 1980, p. 22; G. M. Greenfield, The Challenge of Growth: The Growth of Urban Public Services in Sso Paulo, Tese de Doutorado, Universidade de Indiana, 1975, p. 248; R. Graham, Britain \& the Onset of Modernization in Brazil, Londres, Cambridge University Press, 1972, pp. 116-8.

15. Note-se que a partir de 1850 já se instalava no Rio de Janeiro uma pequena rede domiciliar “com tubos de ferro e a parelhos hidráulicos importados da Inglaterra". Jaime L. Benchimol 
Segundo a literatura, quase $200 \mathrm{mil}$ pessoas pereceram, acometidas pela epidemia, durante 1855-1856. Esta cifra se elevaria consideravelmente se fossem incluídas as mortes ocasionadas por surtos de cólera no Ceará, Rio Grande do Norte, Paraíba, Alagoas e Pernambuco, em 1862, no Rio Grande do Sul e no Rio de Janeiro em 1867, as vítimas da Guerra do Paraguai abatidas pelo mal, os casos fatais do aparecimento da doença em Mato Grosso em 1887, na capital paulista e nas localidades do Vale do Rio Paraíba em 1894. Gradativamente, por força das novas teorias sobre contaminação e contágio e da aplicação subseqüente de medidas enérgicas de quarentena $\mathrm{e}$ isolamento e do saneamento das cidades portuárias, a letalidade se reduziu e a cólera desapareceu das estatísticas nacionais no início deste século (para retornar ao País quase no início de um novo século). ${ }^{16}$

Como em nossos dias, também no século XIX o flagelo abateu-se com violência sobre as populações mais pobres e mal-alimentadas, mais propensas à utilização de águas contaminadas, excluídas das mínimas condições de higiene que o progresso urbano no Brasil já assegurava às camadas sociais mais altas. A historiografia nota a perda de milhares de negros escravos nas cidades e, particularmente no Vale do Paraîba, a perda de grande número de escravos pelos fazendeiros. A população livre, de cor, sofreu igualmente o impacto letal da moléstia. Estima-se que, de modo geral, os negros no Brasil chegaram a dois terços do total de mortos pela cólera. ${ }^{17}$

Os casos da Inglaterra e do Brasil foram aqui apresentados como exemplos das relações entre cólera e organização sanitária. As vastas epidemias de cólera no século XIX tiveram impacto semelhante sobre todos os demais países atingidos, quanto à organização sanitária e aos meios de combate das sociedades humanas contra o microparasitismo do Vibrio comma.

Nos Estados Unidos o flagelo foi considerável em pelo menos três períodos: entre 1832 e 1834, entre 1849 e 1854 e em 1866. Atingiu todo o país - dado o grande intercâmbio entre as várias regiōes, generalizou-se de modo mais intenso do que, por exemplo, no Brasil. Concentrou-se nas maiores cidades portuárias como Nova Iorque e Chicago, mas não poupou

demonstra, no entanto, que a inovaçāo se deveu antes à reduçāo crescente da mão-de-obra escrava que fazia a distribuiçāo da água das antigas bicas, poços públicos e chafarizes, do que à ocorrência de epidemias. Ver J. L. Benchimol, Pereira Passos: Um Haussmann Tropical, Rio de Janeiro, Secretaria Municipal de Cultura, Turismo e Esportes, 1990, esp. pp. $65-72$.

16. L. Santos Filho, História Geral da..., op. cit., pp. 208-11.

17. Cf. D. B. Cooper, "The New 'Black...”, op. cit., pp. 253-4. 
o interior; ceifou a vida de pequenos fazendeiros e estivadores, de trabalhadores nas minas de carvão e escravos do eito, mas atingiu também as camadas sociais abastadas. De modo similar ao Brasil, os governos criaram órgāos sanitários para o combate à epidemia. Ali onde já havia juntas de higiene (como o Board of Health de Nova Iorque), suas funçōes de polícia sanitária foram aperfeiçoadas e consolidadas. Diferentemente do caso brasileiro, e à semelhança dos ingleses, a organizaçāo sanitária teve preponderantemente um caráter local. Organizaçōes de âmbito nacional, como a Junta Central de Higiene criada no Brasil pela Coroa, nunca existiram nos Estados Unidos. ${ }^{18}$

A cooperação médica internacional. Os "medos e terrores" causados pela cólera junto às populaçōes européias, e particularmente a ameaça crescente ao comércio controlado pelas potências imperialistas, acabaram por aproximar as autoridades sanitárias de vários países em torno de um fórum comum de preocupações.

A primeira etapa de cooperação internacional teve início no Egito, em 1831. Os cônsules europeus em Alexandria formaram uma Junta de Saúde para operar um posto avançado, na Ásia, para o rastreamento da "cólera maligna” e difusão das informações epidemiológicas para toda a Europa.

Em Paris, em 1851, deu-se o segundo grande encontro médico internacional para discutir as pandemias de cólera. Nessa reunião, as diversas correntes profissionais, sob pressão cerrada dos interesses das nações européias, envolveram-se em um duro debate acerca dos métodos de quarentena e sua eficácia. Os médicos dos países mediterrâneos, contagionistas, baseavam-se em sua longa experiência de lutas contra a peste bubônica para preconizar a adoção de quarentenas e o isolamento dos doentes para combater o cólera-morbo. De outro lado, uma corrente liderada por médicos e reformadores ingleses insistia nas causas atmosféricas da doença, no papel das emanações pestilenciais provindas dos pântanos, detritos e esgotos, e manifestavam descrença em relação ao emprego de quarentenas.

Já se viu como o saber médico pendeu progressivamente para o lado dos contagionistas, na medida em que, desde os estudos de John Snow, o papel da água contaminada por excrementos e vômitos de doentes se mostrou relevante para a compreensão da etiologia da cólera. Quando, em 1883, um

18. Uma discussão excelente dos anos da cólera nos Estados Unidos encontra-se em C. E. Rosenberg, The Cholera Years: The United States in 1832, 1849 and 1866, Chicago, The University of Chicago Press, 1962. 
grupo de médicos europeus voltou a reunir-se no Egito, as medidas sanitárias ditadas pelos contagionistas já prevaleciam. Como chefe da comissāo alemã enviada ao Egito, Koch encerrou de vez o debate entre estudiosos, ao isolar o vibriāo causador e determinar seus meios de propagação. ${ }^{19}$

A aplicação de princípios científicos à navegação, intensificando os transportes oceânicos, havia tornado possível a internacionalização da cólera. Outros avanços científicos, aplicados à pesquisa médica, permitiam agora o combate à sua propagação. Outros campos da ciência - no tocante à racionalidade administrativa - viabilizaram o surgimento de organizaçōes sanitárias nacionais e internacionais, que, desde entāo, se integraram definitivamente à história dos povos. Em 1909 despontava o embrião de uma organização mundial de saúde: o Escritório Internacional de Higiene Pública, sediado em Paris, com o objetivo de rastrear e estudar possíveis surtos de cólera e outras doenças infecciosas como a peste e a febre amarela.

Ao findar o século XIX, todos os países europeus e americanos por onde passara o flagelo haviam desenvolvido diferentes estratégias de prevenção e combate. A organização administrativa no campo da saúde avançou, com maior ou menor sucesso, em todos os países. Os melhoramentos das condiçōes de saneamento e abastecimento d'água foram expressivos, ainda que só raramente beneficiassem as camadas mais pobres da população. No início do século XX a cólera desapareceu pouco a pouco das estatísticas de morbidade e mortalidade do mundo ocidental, em decorrência do emprego de métodos eficazes de quarentena, do progresso nas condições de saneamento das cidades, do tratamento dos mananciais e utilização do cloro (a partir de 1908$)^{20}$ e da difusāo de padrōes de asseio pessoal a todas as classes sociais.

Entretanto, essas conquistas não se consolidaram nos territórios situados no interior do Golfo de Bengala, nos focos asiáticos seculares do cóleramorbo. Esses verdadeiros nichos ecológicos da doença persistiram ao longo do tempo como uma ameaça permanente de restabelecimento da cadeia infecciosa mundial que perdurou, por cerca de cem anos, a partir de 1817 . Hoje, decorrido quase um século depois de eliminada a última pandemia mundial, de 1896, um conjunto de fatores faz reproduzir as cadeias de propagaçāo da doença. Desde 1970 a cólera tornou-se endêmica nas regiōes

19. W. H. McNeill, Plagues and..., op. cit., pp. 245 e ss.

20. Veja-se H. F. Dowling, Fighting Infection: Conquests of the Twentieth Century, Cambridge, Mass., Harvard University Press, 1977, p. 15. 
do oeste da África e espalhou-se por outras partes do continente. ${ }^{21}$ Novos focos de irradiação surgem por todas as regiōes mais pobres do planeta.

Um novo capítulo será escrito pela historiografia do século XXI, que deverá mostrar às futuras gerações o modo pelo qual os enormes bolsões de miséria em todo o Terceiro Mundo e o crescimento desordenado de cidades com vastas periferias sem água tratada e rede de esgotos acabaram por fazer recrudescer o temível mal durante a presente década. $O$ conhecimento médico atual acerca das causas, sintomas e tratamento da doença contrasta com o rastro de dúvidas que no passado assediavam a profissão médica (e, em decorrência, as autoridades governamentais) em todo o mundo. A cólera existe, hoje, como uma doença social e como tal terá de ser combatida pelos governos e pela comunidade. A existência de antibióticos e de tecnologias mais baratas e eficientes de saneamento básico, a própria acomodação entre o microorganismo e os hospedeiros humanos ao longo do século - trazendo, talvez, certa redução na força letal do vibriāo —, indicam que a propagação da doença em nossos dias é muito menos um problema médico do que uma questão urgentíssima de reforma sanitária e de redistribuição social da riqueza.

No tocante à história das epidemias, o historiador William McNeill, escrevendo em 1976 - cerca de dez anos antes do surgimento de uma pandemia inteiramente nova na história humana, causada pela Aids -, tecia, então, algumas consideraçōes tristemente premonitórias. Segundo McNeill, o controle progressivo das relaçōes ecológicas entre parasita e hospedeiro, desde 1880 , poderia criar certos resultados näo antecipados na história das doenças da humanidade. Por outro lado, as mudanças do vírus da influenza e as mutações de outros organismos infecciosos permanecem, escrevia ele, uma ameaça para as sociedades humanas. Além disso, mesmo sem sofrer mutaçōes, ponderava que parasitas até então obscuros poderiam escapar de seu nicho ecológico e expor populaçōes - cada vez mais adensadas pelo crescimento em escala mundial - a novas experiências de mortalidade.

Como exemplo da instabilidade e imprevisibilidade dos caminhos futuros do microparasitismo na história da humanidade, o historiador norte-americano lembra que o próprio bacilo da cólera — um tipo novo? —, restrito até então às Ilhas Célebes (Indonésia), chegou a deslocar o microorganismo "clássico" da regiāo de Bengala e provocar surtos violentos sem precedentes

21. Cf. L. Doyal e I. Pennell, The Political Economy of Health, Boston, South End Press, 1979, p. 132. 
no subcontinente indiano. McNeill mostra-se pessimista sobre as possibilidades de eliminação de todas as formas de microparasitismo: "As doenças infecciosas", diz ele, "certamente permanecerão um dos parâmetros fundamentais e determinantes da história humana". ${ }^{22}$

\section{II}

\section{Nova Iorque e a cólera no século XIX: crônica de uma cidade ameaçada}

A seguir traçarei brevemente um quadro mais detalhado das relações entre a cólera e uma comunidade atingida, que traz para o primeiro plano todo um conjunto de valores éticos, atitudes e crenças envolvendo as classes sociais e a profissão médica, as instituições religiosas e o governo.

Nossa escolha da cidade de Nova Iorque, devastada inúmeras vezes pelo cólera-morbo durante o século XIX, deve-se à riqueza do material histórico publicado até hoje sobre aquela cidade ${ }^{23}$ e à convicção de que, em que pesem os diferentes contextos socioculturais de Nova Iorque e, por exemplo, Rio de Janeiro ou Recife, o contato entre sociedades humanas e microorganismos parasitas está associado a certos padrões simbólicos (doença como castigo divino, maior suscetibilidade ao contágio por parte de pessoas de comportamento social "reprovável" etc.) que mantêm alguma regularidade em diferentes sociedades históricas.

Charles E. Rosenberg chama a atenção para uma interessante característica da relação entre a cólera e as mudanças sociais na sociedade norte-americana. Segundo o historiador, a cólera era vista por muitos como o flagelo dos pecadores em 1832 (data da primeira grande invasāo da doença), mas em 1866, por ocasião da terceira grande epidemia, já se generalizara a crença da população de que a culpa recaía não no pecado, mas na falta de saneamento..$^{24}$

Um clima "positivista", "um temperamento mais crítico e empírico" havia substituído a devoção piedosa nos lares americanos, tão característica da mentalidade dos primeiros colonos da Nova Inglaterra. Antes de 1850, prevalecia uma interpretação moral das causas e da incidência das doenças.

22. W. H. McNeill, Plagues and..., op. cit., p. 257.

23. A obra clássica sobre o tema é de autoria de C. E. Rosenberg, The Cholera Years..., op. cit. 24. Idem, p. 5. 
A imoralidade e o pecado predispunham o indivíduo a contrair as "pestilências" da época. E as oraçōes, ainda que insuficientes para a cura, eram consideradas um meio apropriado para obtê-la. A medicina doméstica, mais do que a profissional, faria o resto. Essas práticas caseiras de cura, com base em manuais de medicina extremamente populares em todo o país, tornaramse, por vias tortas, um dos meios da secularização das crenças sobre a origem das enfermidades. A partir de 1850 , à medida que uma visão mais natural sobre as doenças se difundia, a medicina doméstica cedia terreno e abria-se caminho para a consolidação da profissão médica e da explicação científica das febres e pestilências.

Em linhas gerais, esse é o pano de fundo da relação entre doença, cultura e sociedade durante o século XIX, nos Estados Unidos, que afetará o modo pelo qual a população nova-iorquina reagirá à devastação de seus lares pela cólera. ${ }^{25}$

Nova Iorque, 1832. Os primeiros sinais da penetração da doença não colheram os habitantes de surpresa. Sabia-se que a ira de Deus só se abateria sobre pagãos, maometanos e "papistas" da Ásia e Europa, ou sobre os miseráveis e mal-alimentados de outras terras. Dificilmente, pensavam os nova-iorquinos, a nova peste asiática poderia atingir uma nação que vivia em liberdade, era educada e muito piedosa.

Entretanto, sabiam, igualmente, que sua cidade era vulnerável, pois possuía antros de pecado e vício, áreas apinhadas de gente, sujas e pobres. Mais do que as imundícies, era o pecado que iria atrair a pestilência. Dizia um jornal local: "A cólera não é causada pela intemperança e pela sujeira, em si mesmas, mas é um flagelo [...] nas mãos de Deus”.

Às primeiras notícias de que a epidemia havia cruzado o Atlântico e já atingira as populaçōes de Quebec e Montreal, no Canadá, muitos nova-iorquinos abastados começaram a abandonar sua cidade. Os imigrantes irlandeses eram olhados com desconfiança. Eram católicos, eram pobres, eram diferentes. As suspeitas pareceram se confirmar nos últimos dias de junho, quando foram diagnosticados os primeiros casos da doença justamente em uma família irlandesa.

A população mais pobre reagiu energicamente às tentativas da Comissão de Salubridade de hospitalizar os doentes. Os hospitais improvisados na cidade (um, por exemplo, foi montado em uma escola, outro em uma antiga

25. Consulte-se o livro magistral de Paul Starr sobre as transformaçōes da medicina na sociedade norte-americana do século XVIII aos nossos dias. P. Starr, The Social Transformation of American Medicine, Nova Iorque, Basic Books, 1982. 
agência bancária) eram considerados, com razão, simples "ossários" ou casas da morte. Médicos e funcionários municipais que tentavam internar os doentes eram espancados e expulsos.

Por outro lado, a própria população discriminava brutalmente os doentes. Ainda que o argumento contagionista tivesse pouco ou nenhum prestígio entre os médicos, o vulgo temia o contágio pelo contato direto com infectados. Habitantes de outras cidades, por esse motivo, mostravam-se hostis para com os nova-iorquinos que, em fuga, procuravam abrigo em lugares até então indenes.

Aqueles que viam na cólera uma manifestação da ira divina acabavam por aceitar a profilaxia de sangrias e purgativos, como o calomelano, receitado pelos médicos e pela Comissão de Salubridade. Os clérigos de todas as denominações pregavam a necessidade de os fiéis seguirem os preceitos da ciência contra as enfermidades, pois aqueles eram também os desígnios de Deus. Mas, acima de tudo, a obediência aos preceitos da vida religiosa protegeria seu rebanho das devastaçōes mortíferas.

As explicações científicas que chegavam aos habitantes eram variadas e ambíguas, enfatizando esse ou aquele elemento em um vasto conjunto de fatores morais, mentais, clịmáticos e higiênicos. A teoria atmosférica preponderava e ligava-se convenientemente à teoria das predisposiçōes: como a teoria dos miasmas não podia dar conta do fato de que alguns contraíam a doença $e$ outros não, em uma mesma rua ou até em uma mesma casa, as predisposições proviam o elo explicativo que faltava àquela teoria. Quem vivesse em áreas de "emanações pestilenciais" poderia ser menos predisposto a contrair a cólera se vivesse uma vida sem pecado, se trabalhasse dignamente, se se abstivesse de bebidas alcoólicas. O povo, entretanto, secretamente, era contagionista: Rosenberg lembra que as autoridades sanitárias tinham sempre uma grande dificuldade de alugar prédios residenciais que pudessem ser transformados em enfermarias. Mais ainda, era extremamente difícil encontrar enfermeiras que aceitassem trabalhar nessas casas de contágio e morte.

No fim do ano de 1832, a epidemia havia cessado. A alta mortalidade, a fuga dos moradores, a chegada das baixas temperaturas do inverno contribuíram para a redução e eliminação dos focos da enfermidade. ${ }^{26}$

Nova Iorque, 1849. Nova Iorque havia crescido muito desde a primeira pandemia, mas de modo algum se tornara mais limpa. Certas áreas eram

26. C. E. Rosenberg, The Cholera Years..., op. cit., parte 1. 
imundas, miseráveis, seus moradores disputando os espaços na rua com os porcos.

Em 1848, a doença já atravessara o Atlântico e atingira, pelo Golfo do México, o sul dos Estados Unidos. Pelo porto de Nova Orleans e através do Mississipi, o mal penetrara no interior do país. As temperaturas baixas do inverno mantiveram o surto circunscrito à regiâo sul, mas as autoridades já prenunciavam que alcançaria as cidades mais ao norte no início da primavera. Assim se deu, e em Nova Iorque a Orange Street apresentou o primeiro foco da cólera, em um cortiço em que viviam dezenas de pessoas. Isto ocorreu em maio, e ainda nesse mês o Board of Health municipal montou o primeiro hospital para pacientes (especialmente moribundos) de cólera.

As teorias contagionistas já recebiam maior crédito nessa época. A população, que jamais deixara de recear a transmissão pelo contágio fosse ou não pela ira de Deus, fosse ou não por condiçōes atmosféricas adversas e predisposições pessoais "mórbidas" —, sentia-se agora fortalecida em seus temores. Por isso, insurgiu-se contra a Comissão Municipal quanto esta tomou de aluguel o segundo andar de uma taberna para instalação de uma enfermaria para pacientes de cólera. A localização em área urbana atemorizou os habitantes, que procuraram atear fogo ao edifício e tiveram de ser contidos por força policial. Esses hospitais de isolamento representavam, na imaginação popular, lugares onde os poucos médicos disponíveis realizavam experiências com os moribundos. Apenas os abandonados por suas próprias famílias acabavam seus dias nessas pesthouses; famílias respeitáveis, dizia-se, não deveriam consentir nem mesmo que seus empregados dessem entrada em tais hospitais, mas que fossem deixados morrer - isolados do contágio - nas residências.

Para os moradores aterrorizados de 1849 e 1832, a religiosidade ainda os predispunha fortemente a ver na epidemia o merecido castigo divino para o materialismo e o pecado. Tendo se espalhado por todo o país, o presidente Taylor chegou a estabelecer um dia nacional de oraçōes e jejum contra a cólera. Como os habitantes de outras regiōes varridas pela terrível pestilência, os nova-iorquinos também esperavam que a graça divina iluminasse as autoridades sanitárias. Antes que tal sucedesse, mais de 5 mil pessoas pereceram entre maio e agosto de 1849 , último mês da segunda epidemia. (Nova Iorque, na verdade, sofreu menos que outras cidades norte-americanas, onde a cólera permaneceu por muito mais tempo.)

Mas havia alguns sinais de mudança na atitude geral da população diante da epidemia. Ainda se recriminavam os "excessos sexuais", a intemperança, a existência de bêbados e prostitutas, ainda se via a ira divina no recrudes- 
cimento da cólera. Mas, na tensão entre a moral, a religião e a ciência, esta começava a ganhar mais espaço nas mentes dos indivíduos. Havia até mesmo líderes da pequena comunidade médica - cuja autoridade se consolidaria depois de meados do século - que partilhavam uma visão talvez piedosa sobre as enfermidades. Por exemplo, um professor de medicina da Filadélfia chegou a afirmar a seus estudantes que apenas a vontade de Deus poderia explicar a volta da epidemia tantos anos depois. Entretanto, esta era, já, uma voz isolada. A autoridade profissional procurava alicerçar-se sobre explicaçōes de natureza científica, que enchiam as páginas das revistas médicas. "Deus parecia fora de lugar em uma revista médica", esclarece Charles Rosenberg. ${ }^{27}$

O progresso das ciências naturais parecia colocar ao alcance das autoridades sanitárias certas leis sobre a incidência das doenças e suas causas. Mas a tensão persistia na metade do século: uma curiosa mistura de ciência e religiosidade seria, talvez, a característica predominante. Um interessante exemplo do clima predominante pode ser visto na explicação sobre cólera e conduta moral, que fazia uso de uma argumentação "científica": um clérigo do Estado de Indiana afirmava ter concluído, depois de somar as mortes por cólera em sua comunidade, que havia "uma diferença de 55 para 17 em favor dos hábitos de uma vida religiosa”. A tensão entre ciência médica, religião e moralidade perduraria, ainda, no decurso das últimas décadas do século XIX.

Nova Iorque, 1866. Os Estados Unidos acabavam de enfrentar uma Guerra de Secessão, e a cólera retornou às grandes cidades que atacara já por duas vezes, em 1832 e 1849 . A epidemia difundiu-se indiscriminadamente entre unionistas do Norte e confederados do Sul. Entretanto, Nova Iorque foi poupada dos rigores do flagelo. A epidemia, que refizera o itinerário ÁsiaEuropa-Américas, reduziu-se a um breve surto na cidade de Nova Iorque, durante o verão de 1866 , provocando apenas uma fração das mortes ocasionadas em 1849. O que mudara, desde então?

A grande mudança se deu no âmbito da organização sanitária da cidade, fruto de nova legislação estadual. A antiga Junta de Higiene de Nova Iorque era alvo de críticas constantes e cinco propostas de mudanças na legislação existente já haviam sido apresentadas às duas Câmaras Estaduais, sem sucesso. Um grupo de cidadāos reformistas formou uma Citizen's Association e esta associação civil, por sua vez, inspirou vários médicos a conduzirem um levantamento das condições sanitárias da cidade. As conclusōes do relatório, publi-

27. Idem, p. 127. 
cado em 1865 , foram alarmantes. Uma nova proposta de reforma da organização da saúde foi redigida por um conselho da Associação.

No início de 1865 , ante a ameaça de chegada da epidemia, os grupos reformistas acreditaram que, afinal, existia clima favorável para uma nova legislação. As reformas realizadas em Londres e Paris e em algumas cidades nos Estados- Unidos, como Providence e Filadélfia, eram citadas como exemplos a serem seguidos. Argumentava-se que uma nova Junta de Higiene, mais atuante, com funções e poderes ampliados, não apenas protegeria a cidade de Nova Iorque contra a epidemia, mas ainda melhoraria em definitivo as próprias condições sanitárias das habitações e vias urbanas.

Em fevereiro de 1866, sob a pressão dos grupos profissionais e demais setores das classes médias, a Assembléia Legislativa aprovou uma lei que criava um Distrito Sanitário Metropolitano, compreendendo os municípios de Nova Iorque, Queens e vizinhanças. Estabelecia-se também a Junta de Higiene Metropolitana, cujo âmbito de atuação se estendia a toda a área do Distrito. Os membros da Junta deveriam ser higienistas e esperava-se que as nomeações não tivessem caráter político. Ela seria formada por um presidente, quatro comissários de polícia ( $\mathrm{sic}$ ), um inspetor de saúde dos portos e quatro médicos.

A organização administrativa, porém, seria insuficiente (apesar do poder de polícia assegurado à Junta recém-criada) para prevenir o avanço da epidemia. Era preciso que a Junta se apoiasse em preceitos corretos de saúde. Ora, a década de 1860 ainda estava longe das descobertas bacteriológicas que dariam novo embasamento científico às políticas sanitárias da época. Rosenberg alerta para o perigo de criarmos um cenário inexistente: a Junta de Higiene Metropolitana não estava adiante de seu tempo. A antiga tensão entre ciência e religiosidade persistia. Os miasmas ainda proviam as explicações mais correntes sobre a origem da doença.

Entretanto, os resultados positivos das quarentenas nas poucas oportunidades em que eram adotadas com rigor, a experiência de John Snow na Inglaterra e o impacto crescente de suas idéias, a ineficácia de medidas sanitárias que se restringiam à drenagem de pântanos e à limpeza das cidades para eliminar os temidos miasmas, este conjunto de fatores acabou por criar um terreno favorável aos contagionistas. Mais que isso, à medida que as teorias sobre as causas atmosféricas cediam terreno, a cólera passava a ser considerada uma moléstia "específica", com características próprias. Já perdiam crédito, entre os facultativos, as teorias nebulosas sobre as diarréias poderem transformar-se em cólera, sobre esta se converter em tifo etc. "Médicos que acreditassem em algum tipo de 'teoria dos germes' eram 
ainda uma minoria insignificante", afirma Rosenberg, "mas já eram ouvidos; não eram desprezados com palavras casuais de zombaria". ${ }^{28}$

Muitas outras cidades norte-americanas, como Chicago, passaram a adotar esquemas de organização sanitária pautados no exemplo de sucesso que se atribuía à Junta de Higiene Metropolitana de Nova Iorque. O evangelho da saúde pública competia agora com o da moral e da religião. Ainda que as "predisposições mórbidas" fossem sempre de natureza moral ou religiosa vida desregrada, "lascívia” etc. - , estas causas imediatas se harmonizavam perfeitamente com as teorias contagionistas, do mesmo modo como se harmonizaram em 1832 e 1849 com as não-contagionistas, que tratavam das causas últimas da doença. Ou seja, no interior de uma comunidade exposta ao contágio sempre haveria algumas boas almas poupadas pela cólera. Inversamente, os mais predispostos seriam os pecadores, os homens e mulheres de má conduta. Mas a partir de meados da década de 1860 , esse conjunto de crenças coexistia com um credo social reformista, com uma moral higienista. A populaçāo, atenta até então somente à prédica dos púlpitos, voltava-se também para o credo dos médicos, advogados e políticos ligados à reforma sanitária.

Depois das mudanças na legislação e nas ações conduzidas pela Junta de Higiene Metropolitana de Nova Iorque, "nenhuma cidade poderia chamar-se civilizada se negligenciasse temas tão mundanos como esgotos, escoadouros e poços". ${ }^{29}$ Quanto à higiene pessoal, prescreviam-se cuidados diários com a limpeza corporal, a atenção aos banhos e ao asseio dos lares - nada disso se chocava com os valores puritanos dos protestantes. A preocupação com a saúde espiritual deveria somar-se ao zelo com a higiene do corpo. A epidemia de cólera, pregava o reverendo George Templeton Strong, "é o julgamento de Deus sobre os pobres por descuidarem de Suas leis sanitárias". ${ }^{30}$ Curiosa combinação das leis de Deus com os preceitos do novíssimo evangelho da higiene pública.

Se se compararem os três períodos de invasão da nova peste, a força das explicações religiosas era ainda expressiva, mas se reduzira consideravelmente à época da terceira epidemia nos Estados Unidos. Por exemplo, o jejum, como atitude piedosa e pedido de clemência à ira de Deus, só raramente foi prescrito pela Igreja durante a terceira epidemia. ${ }^{31}$ Quanto ao poder temporal, o incremento do poder dos sanitaristas (tanto médicos como

28. Idem, p. 199. A discussão mais ampla sobre este ponto está em todo o capítulo XI.

29. Idem, p. 215.

30. Apud idem, p. 217.

31. Idem, p. 220. 
engenheiros, advogados e outros profissionais militantes da nova causa) não se fizera acompanhar do acréscimo de prestígio entre os médicos clínicos. $O$ poder de cura era reduzido, e talvez se possa dizer que a prescrição de remédios menos violentos, por ocasião dos últimos surtos, pudesse ser mesmo responsável pelo menor número de óbitos. Mas o argumento que prevalecia era, sem dúvida, o preventivo, não o curativo.

Se, para os norte-americanos, a pandemia que colheu o país em 1832 parecia ser, preponderantemente, um reflexo de problemas de ordem moral, em 1866 transformara-se - à semelhança de cento e tantos anos depois em questão social. Os valores científicos, em sentido amplo, haviam abandonado a velha roupagem "racionalista" e vestido a do "empirismo". Esta nova mentalidade afetava os escritos médicos, a imprensa e, como vimos, até mesmo o púlpito. ${ }^{32} \mathrm{~A}$ cólera atuara como uma força catalisadora de mudanças no clima intelectual de toda a América do Norte, projetando a saúde pública para o centro dos valores e preocupaçōes dos indivíduos.

Até que ponto os preceitos da Junta de Higiene Metropolitana de Nova Iorque foram seguidos? Até que ponto as desinfeç̧öes, o isolamento e a quarentena foram empregados com rigor? Os bolsões de pobreza da cidade foram servidos por sistemas de esgotos e ganharam acesso a poços de água não-contaminada? A literatura não proporciona respostas seguras a estas questōes. Mas não resta dúvida que Nova Iorque foi poupada dos rigores da pandemia de 1866 e a cólera jamais voltou a assumir proporçōes graves como no passado. O certo é que, sob o ângulo da mentalidade científica e das políticas governamentais, os créditos atribuídos ao desempenho da Junta de Higiene Metropolitana de Nova Iorque pela opinião pública fossem ou não totaimente merecidos — produziram um efeito multiplicador em toda a sociedade americana e contribuíram para a consolidação da reforma sanitária, particularmente nas regiões mais ricas do país.

\section{III}

A história comparativa traz sempre possibilidades inesgotáveis para que um mesmo fenômeno social seja reavaliado sob múltiplos ângulos. Assim é com a história da cólera. Um observador norte-americano, por exemplo, partindo da experiência isolada de seu país, concluiria que órgãos locais de

32. Idem, pp. 214,228 e 232. 
saúde pública (a exemplo dos existentes em grandes cidades como Nova Iorque, Chicago e Boston) teriam sido suficientes para desencadear a reforma sanitária e a renovação urbana em todo o mundo. No entanto, se ele se debruçasse sobre a experiência brasileira com a cólera, verificaria que órgãos centrais - nossa Junta Central de Higiene Pública - tiveram papel destacado na criação de normas e na agitação do tema das epidemias em todo o Brasil. A distinta formação do Estado nacional em cada um desses países e seu relacionamento diferenciado com a sociedade marcaram profundamente o caráter e a função dos aparelhos administrativos no campo da saúde pública nos dois países. ${ }^{33}$

Outras singularidades merecem destaque. Nas nações anglo-saxãs, a estreita vinculação das "doenças pestilenciais" à religiâo e à moral — como um castigo divino aos pecadores - marcou fortemente as crenças das elites e da população em geral. Alguns líderes do movimento sanitário nos Estados Unidos e na Inglaterra foram até mesmo homens de "profundo sentimento religioso". ${ }^{34}$ Os estudos históricos sobre o Brasil, apesar de indicarem a grande participação das irmandades e outras associações religiosas no tratamento dos doentes e no estabelecimento de enfermarias de emergência, ${ }^{35}$ não esclarecem as diferenças entre as concepções protestantes e católicas sobre a origem das enfermidades. Aparentemente, as crenças existentes no seio da população brasileira não estabeleciam, de modo tão patente como nos países protestantes, os elos entre condutas ditas pecaminosas e a irrupção das epidemias. Mas havia, sem dúvida, julgamentos de natureza moral sobre a maior suscetibilidade de pessoas de vida irregular, como prostitutas, contraírem doenças malignas como a cólera.

Umi aspecto bastante peculiar aos norte-americanos era a atribuição aos imigrantes da responsabilidade pela difusão das doenças. As crenças sobre o contágio facilitavam tais suposiçōes. Como vimos, mesmo em pleno apogeu da explicação miasmática a população norte-americana permanecia adepta das noçōes contagionistas. Os pobres em geral - por levarem vida "irregular" e por ser a própria pobreza uma afronta a Deus - eram considerados uma fonte certa de contágio. Os negros incluíam-se nesse "grupo de risco". Mas para toda a população, e mesmo para os pobres, eram os imigrantes o objeto especial de

33. Uma análise da evolução da saúde pública no Brasil, no quadro mais amplo da formação do Estado nacional, encontra-se em L. A. de Castro Santos, Power, Ideology and Public Health in Brazil, 1889-1930, Tese de Doutorado em Sociologia, Universidade de Harvard, 1987. 34. Idem, pp. 228-9.

35. L. Santos Filho, História Geral da..., op. cit., p. 210. 
discriminação. Os irlandeses, na mißjria muito pobres e moradores em áreas miseráveis das cidades, e além disso católicos, recebiam em cheio a carga da culpa pelo alastramento das epidemias. Se a história mostra, hoje, que as correntes imigratórias - na falta de medidas rigorosas de quarentena e isolamento - estabeleceram de fato um elo de propagação das epidemias entre países e continentes, também é fato que a atribuição indiscriminada de culpa ao estrangeiro foi, e ainda permanece em nossos dias, um mecanismo perverso de transferência de responsabilidades às minorias. Em suma, as vítimas transformam-se em culpados. No caso norte-americano, a discriminação cedo cristalizou-se em estigma brutal contra os irlandeses.

No Brasil a situação foi outra. Por ocasião das investidas mais graves da doença os movimentos migratórios internacionais ainda não buscavam o Brasil. Só mais tarde, durante os anos de 1880 , teve início o movimento de entrada de grandes contingentes de europeus nos portos brasileiros, que se estenderia durante várias décadas. Esse período, todavia, foi posterior às epidemias do cólera-morbo no País. Esclareça-se, no entanto, que nem sempre as minorias foram poupadas. À falta de um grande número de imigrantes durante as epidemias, a atribuição de responsabilidade pela disseminação da moléstia atingiu, por exemplo, um pequeno grupo de ferroviários irlandeses, empregados na construção do trecho inicial da Estrada de Ferro D.Pedro II (hoje Central do Brasil), próximo à Capital. ${ }^{36}$ Dizia-se que esses estrangeiros viviam na "intemperança" e no desregramento sexual, tornando-se por isso vítimas fáceis da cólera, disseminando-a pela população brasileira. De modo geral, o estigma do risco de contágio recaía igualmente sơbre brasileiros que se julgava terem conduta moral duvidosa: nesse caso, os negros - livres ou escravos - não escapavam à discriminação.

A profissão médica gozava de menor prestígio nos Estados Unidos do que no Brasil: aqui o tradicionalismo e o conservantismo das elites abriam menor espaço às seitas médicas do que nos Estados Unidos, a tradição centralizada da Monarquia permitia algum controle do exercício profissional nas cidades e nossas tradições ibéricas de ensino médico eram responsáveis por normas mais rígidas de formação dos facultativos brasileiros. (Charles Rosenberg revela o descrédito de que padeciam os médicos nos Estados Unidos até pelo menos 1850, ao notar que os Estados da Carolina do Sul, Maryland e Nova Iorque chegaram a remover, entre 1838 e 1844 , todas as restrições legais ao exercício da profissão médica. ${ }^{37}$ )

36. Cf. D. B. Cooper, “The New 'Black'...”, op. cit., p. 248.

37. C. E. Rosenberg, The Cholera Years..., op. cit., p. 155. Veja-se, também, sobre o “antipro- 
Mas näo apenas nos Estados Unidos havia o que hoje denominamos medicina alternativa. Médicos homeopatas - seguidores da lei dos similares, defendida pelo médico alemão Samuel Hahnemann - tinham boa clientela no Brasil, particularmente nas camadas sociais abastadas. Sua penetração junto às elites ainda na primeira metade do século XIX quando mal se consolidara o ensino médico nas Escolas do Rio de Janeiro e da Bahia - fez com que ganhasse considerável legitimidade, apesar das resistências dos profissionais "alopatas". Até o fim do século XIX, escreve Lycurgo Santos Filho, a homeopatia teve "notável impulso" no Brasil. ${ }^{38}$

Nesse sentido, em que pesem as distinções já assinaladas, o cenário profissional guardava algumas semelhanças entre os dois países. Durante as epidemias de cólera nos Estados Unidos e no Brasil, os homeopatas tiveram papel destacado, juntamente com médicos "botânicos" e adeptos da hidroterapia (que praticavam a cura pelas águas). As epidemias abriam espaço para tratamentos alternativos. Quando a população se desesperava diante do fracasso do emprego de métodos tradicionais para o combate aos surtos devastadores, não havia meios de cercear o exercício profissional às mais variadas denominações médicas.

Nas cidades norte-americanas, segundo Rosenberg, ainda que a maioria dos médicos continuasse a seguir a terapêutica tradicionalmente violenta (sangrias, suadouros, vomitórios), os médicos das escolas de elite como Harvard e Pensilvânia, ou formados em clínicas de Paris, Londres ou Dublin, reagiram ao avanço das terapêuticas rivais adotando tratamentos menos traumáticos e uma visão mais crítica sobre os ensinamentos tradicionais. No espaço criado pela fragilidade do sabèr médico tradicional e por seu insucesso diante da cólera avançaram ainda mais as doutrinas e práticas concorrentes. Sociedades médicas homeopáticas, como as de Nova Iorque e Pensilvânia, ganharam voz no interior das Juntas de Higiene e em cidades como Nova Iorque homeopatas conquistaram o direito de dirigir algumas enfermarias para pacientes de cólera. ${ }^{39}$

No Brasil, os métodos menos violentos preconizados pela homeopatia no tratamento da cólera também granjearam popularidade. Aos medicamentos

fissionalismo" que vigorou durante o período jacksoniano, P. Starr, The Social Transformation..., op. cit., cap. 1.

38. Os homeopatas baseiam-se na lei dos efeitos similares, segundo a qual o medicamento correto, se aplicado a pessoas sâs, produziria nestas os sintomas do doente. Consultar L. Santos Filho, História Geral da..., op. cit., pp. 388-402; e A. Porto, A Participaçāo dos Homeopatas na Epidemia de Cholera-Morbus de 1855, Casa de Rui Barbosa, 1991, mimeo.

39. C. E. Rosenberg, The Cholera Years..., op. cit., pp. 223-4. 
prescritos para o tratamento - Veratrum album, Cuprum metalicum e Arsenicum album - atribuía-se a vantagem adicional de serem também indicados para a prevenção do mal. ${ }^{40}$ Além disso, durante a epidemia de cólera os homeopatas não descuravam de aconselhar a população a cuidar da higiene pessoal e dos hábitos alimentares. A simpatia que conquistaram junto à população se traduziu, por exemplo, no sucesso da promoção de subscriçōes entre negociantes cariocas para custear uma enfermaria homeopata na Santa Casa. Segundo dados colhidos pela historiadora Angela Porto, a mortalidade entre pacientes com cólera nas enfermarias homeopatas da Santa Casa de Misericórdia do Rio de Janeiro teria sido pelo menos a metade da mortalidade verificada nas outras enfermarias. ${ }^{41}$

Houve distinçōes importantes no modo pelo qual as nações européias e as Américas sofreram os efeitos do flagelo. Fundamentalmente, a epidemia teve um caráter mais “político" na Europa do que no continente americano.

Como salienta Richard Evans, “a progressão do flagelo através da Europa na década de 1830 foi marcada por uma série de motins e agitaçōes em quase todos os países”.42 A população julgava-se vítima de um complô dos governantes ou das elites para reduzir o número de pobres, envenenando-os. Poucos acreditavam, então, que se tratava de uma nova doença. Na Hungria, em 1831, depois de um violento surto de cólera, uma multidão saqueou castelos e assassinou nobres, responsabilizando-os pelo "envenenamento" de poços e reservatórios utilizados pela população. ${ }^{43}$ Por outro lado, adotados pelos governos, os cordöes sanitários produziam dificuldades para a livre circulação de bens e víveres, reduzindo sua disponibilidade e elevando os preços. Nesses casos, a população revoltava-se contra essas medidas consideradas draconianas, e envolvia-se em distúrbios e lutas contra as autoridades. 44

As conseqüências da agitação popular cedo se fizeram sentir. Na Inglaterra, em seguida à onda de protestos em outras regiões da Europa, as

40. Consulte-se o cuidadoso trabalho de A. Porto, A Participaçāo dos..., op. cit., p. 4.

41. Idem, pp. 5-6.

42. R. J. Evans, “Épidemies et Révolutions: Le Choléra dans I'Europe du XIXe. Siècle”, in J. P. Bardet et alli, Peurs et Terreurs..., op. cit., p. 117. (Tradução de "Epidemics and Revolutions: Cholera in Nineteenth-Century Europe", Past and Present, vol. 120, agosto de 1988, pp. 123-46.)

43. Idem, p. 124.

44. A exemplo do que ocorreu em Konigsberg, na Prússia Oriental, em 1831. Idem, pp. 125 e 127. 
medidas oficiais de quarentena e de hospitalização em massa foram suspensas. Em 1832, não só a Ingiaterra, mas a Áustria e a Rússia já haviam abandonado ações rigorosas de combate à disseminação da doença. Como se vê, as agitaçōes sociais contra a polícia sanitária acabaram somando-se à força das doutrinas liberais para reduzir e mesmo eliminar, durantes décadas, as práticas de quarentena e de isolamento de doentes na Europa.

Não se afirma aqui que a cólera fosse a "causa" de levantes revolucionários, ${ }^{45}$ ainda que fosse considerada por muitos, à época, "uma infecção revolucionária". Na verdade, ela se fez presente durante períodos conturbados da história política européia do século passado, mas não chegou a constituir um fator determinante das agitações populares. Por vezes, foi claramente uma conseqüencia das crises sociais e de períodos críticos de pobreza e escassez de alimentos.

No continente americano, nada houve que se assemelhasse aos temores da população européia de que fosse vítima de planos de extermínio por parte dos governos, por meio do envenenamento das águas dos poços. Quando a cólera atravessou o Atlântico, as populações americanas já acreditavam na existência de uma nova doença, de uma nova Peste, cuja devastação nada tinha a ver com supostos planos de envenenamento dos pobres.

Na América do Norte, onde o industrialismo e a circulação comercial foram intensos durante o Século da Cólera, as pressões contra as ações impopulares de polícia sanitária também se teriam feito sentir se - enfatize-se a condicional - tais medidas tivessem se pautado pelo mesmo rigor com que foram implementadas pelas autoridades européias. Entretanto, na ausência de medidas rigorosas na América do Norte - em parte pela própria notícia das revoltas populares européias, em parte pela fragilidade e inoperância dos órgãos sanitários locais, em parte pelo descrédito das teorias contagionistas - atenuou-se a dimensão política da epidemia. Os distúrbios resumiram-se aos protestos em cidades como Nova Iorque (já referidos em seção anterior) contra a instalação de enfermarias para coléricos em zonas residenciais.

A incursão da cólera no Brasil revelou-se também diferente da experiência européia. A Casa de Bragança brasileira não foi incomodada por motins ou revoltas relacionados com a entrada do flagelo, como se dera por exem-

45. Do mesmo modo, a Revolta da Vacina, no Rio de Janeiro, em 1904, não foi causada pela polícia sanitária de Oswaldo Cruz, mas decorreu de um conjunto de fatores de ordem social e política, aos quais se somou a questāo da vacina como um elemento detonador da Revolta. Veja-se L. A. de Castro Santos, Power, Ideology.., op. cit., pp. 108-18, esp. p. 111. 
plo com os Habsburgo. A grande popularidade das doutrinas sobre os miasmas, em relação ao contagionismo, desestimulou a adoção daquelas práticas de controle sanitário responsáveis pela resistência popular na Europa. Por outro lado, mesmo quando providências mais severas de controle passaram a ser adotadas, os interesses comerciais, de pequena expressão, pouco tiveram a perder com as políticas de quarentena e outras limitaçōes à livre circulação de bens e pessoas. Assim, tudo indica que, à proporção que a cólera seguia seu curso da Europa para as Américas, perdia gradativamente o impacto político. Despolitizava-se, por assim dizer.

Retomando, por fim, o curso global da doença, durante todo o século XIX a epidemia nutriu-se de condições propícias para o alastramento do vibrião: significativos movimentos populacionais entre países e continentes, urbanização rápida e proliferação de habitações coletivas nas cidades, baixos padrões de higiene, redes de esgotos e de suprimento d'água precárias ou inexistentes.

Como sugerimos no início deste artigo, visto de modo global o flagelo da cólera trouxe uma verdadeira ruptura epidemiológica na história das sociedades do século XIX. Por caracterizar-se como um forte rompimento na "convivência" entre microparasitas e hospedeiros humanos, atingiu todas as faixas etárias da população; desencadeou pânico e dor no seio das famílias atingidas pela epidemia, particularmente entre os pobres e desnutridos; mobilizou as populações contra minorias, estigmatizadas por razões morais ou religiosas; fortaleceu o papel de líderes religiosos, abalou o prestígio de antigas doutrinas médicas e abriu espaço para a concorrência de doutrinas rivais; estimulou governos e aparelhos administrativos no combate à doença e a criação de uma "polícia médica" em diversos países.

Essa ruptura, de caráter universal, assinalou as condiçōes de surgimento e o impacto epidemiológico da cólera. Não se conclua, entretanto, que as marcas profundas deixadas pelo flagelo na história do século XIX se traduzam apenas pelo número de mortos que provocou. A importância do fenômeno durante todo o século XIX deveu-se antes a seu impacto psicológico, social e epidemiológico, destacado no presente estudo, do que a razões estritamente demográficas. A cólera não esteve entre as primeiras causas gerais de mortalidade durante aquele século, a não ser em períodos curtos, de epidemias ou de surtos localizados, como em 1831-32, 1854 etc. ${ }^{46} \mathrm{Se}$

46. No Brasil, como já nos referimos, estima-se em mais de 200 mil o número de mortes causadas pelo cholera-morbus em todas as províncias entre 1855 e 1894. Cf. L. Santos Filho, 
excetuarmos as molésticas causadoras de mortalidade infantil, como a escarlatina, a difteria e o sarampo, as doenças que mais ceifaram vidas naquele século foram a tuberculose e o tifo. ${ }^{47}$ Precisamente por terem se firmado na memória coletiva como um evento cotidiano, como uma visita "esperada", essas doenças não tiveram o efeito psicológico devastador que a cólera trazia sobre as populações ameaçadas.

O ímpeto com que assolava as populaçōes durante períodos curtos, tomando-as, literalmente, de assalto; a violência com que derrubava suas vítimas, tais eram as características terríveis da penetração da cólera - não era raro que pessoas que estivessem aparentemente sās pela manhā, revelassem sintomas gastrointestinais muito fortes pela tarde e falecessem ao anoitecer ${ }^{48} \mathrm{Em}$ que pese o efeito demográfico reduzido, a "cólera asiática" teve consequêencias dramáticas em todo o mundo, que procurei assinalar no presente texto. No rastro das consequeencias que trouxe para a história epidemiológica da humanidade, o itinerário de dor e medo foi seu mais triste legado.

Apesar de revelar em nossos dias reflexos demográficos ainda mais reduzidos, seu itinerário cruel se refaz entre as populações mais pobres do Terceiro Mundo. Tampouco se configura hoje uma nova "ruptura epidemiológica", no sentido rigoroso do termo. Mas de que servem estas considerações para uma família de peruanos, brasileiros ou indianos, quase sempre os mais miseráveis e famintos, ao serem atingidos brutalmente pela doença?

História Geral da.., op. cit., pp. 208-11; e D. B. Cooper, "The New 'Black...", op. cit., p. 251. Na Inglaterra, a maior devastaçāo se deu por ocasiāo da segunda e terceira epidemias, entre 1848 e 1854 - cerca de 250 mil mortes devidas à cólera. Consulte-se R. Hodgkinson, ed., Public Health in the Victorian Age, vol. 1, Londres, Gregg International Publishers, 1973, esp. "Introduction", p. 3.

47. Consulte-se L. Doyal e I. Pennell, The Political Economy..., op. cit., p. 54.

48. Esta açāo violenta e rapidíssima da cólera sobre a população - particularmente sobre a populaçāo mais pobre e subnutrida - , assinalada por Donald B. Cooper, ainda se observa em nossos dias em países do Terceiro Mundo. (O Brasil, entretanto, tem revelado poucos casos de morte, devido à rápida hospitalizaçāo das vítimas. A f́ndia apresenta a situaçấo mais trágica deste ponto de vista.) 


\section{RESUMO}

\section{Um Século de Cólera: Itinerário do Medo}

A sociologia histórica tem no método comparativo uma de suas ferramentas de trabalho imprescindíveis. Ao focalizar um século de epidemias de cólera em alguns países, o autor procurou demonstrar como um mesmo fenômeno histórico-social, estudado comparativamente, revela contrastes marcantes em seu impacto sobre a cultura, a sociedade e a política, em distintos lugares e através do tempo. Por exemplo, os diferentes processos de formação do Estado nacional marcaram profundamente a natureza dos aparelhos administrativos em países diversos, levando cada nação a desenvolver organizaçōes sanitárias diferenciadas e modos diferenciados de combate às epidemias de cólera. Por outro lado, a análise histórico-comparativa permite entrever, no interior de cenários dissimilares, alguns padrões regulares de relacionamento entre doença e sociedade. Assim é que, apesar das diferenças que afetaram, em diversas comunidades nacionais, os valores éticos, as crenças e os comportamentos das classes sociais, da profissão médica, dos grupos religiosos e dos governos diante da cólera, houve alguns padrōes simbólicos praticamente invariáveis: a análise comparativa permitiu detectar, por exemplo, que, fosse no Rio de Janeiro ou em Nova Iorque de meados do sécu lo passado, a cólera era considerada por todos um castigo divino, que atingia primeiramente as pessoas de comportamento social "reprovável”. Neste artigo, o relato da tragédia humana vivida por Nova Iorque diante da cólera atende a um duplo objetivo: revelar como uma sociologia do cotidiano pode demonstrar a complexa interaçāo doença, indivíduo e sociedade em uma metrópole do século XIX; e como, na análise de outra experiência histórica - a norte-americana - pode-se descobrir fortes contrastes e semelhanças com o Brasil, fazendo do estudo de outra realidade um desafio para o conhecimento dos modos de enfrentamento da doença epidêmica pela população brasileira. Considerando-se seus efeitos macro-históricos, o aumento dos níveis de mortalidade foi bem menos brutal que seu impacto social e psicológico - o terror gerado pela cólera no cotidiano das famílias. Do ponto de vista epidemiológico, viu-se neste artigo que as epidemias foram geradas na Ásia por uma grande ruptura no equilibrio entre microparasita e hospedeiro humano - ruptura resultante, por sua vez, dos movimentos populacionais intensificados pelo imperialismo europeu. Partindo da Índia, as ondas epidêmicas propagaram-se velozmente pela Europa e Américas, afetando sobretudo as populaçōes mais pobres e residentes em 
áreas insalubres. Este é o quadro geral discutido no presente artigo, em que a sociologia histórica toma de empréstimo à epidemiologia histórica de William McNeill algumas de suas análises mais esclarecedoras.

\section{ABSTRACT \\ A Century of Cholera: An Itinerary of Fear}

The comparative method is one of historical sociology's indispensable tools. Focusing on a century of cholera epidemics in a number of countries, the present comparative study endeavors to show how one same historicalsocial phenomenon displays sharp contrasts across time and space in the impacts it has on culture, society, and politics. For example, dissimilar state-building processes have left deep marks on the nature of administrative apparatuses in different countries, leading each nation to develop its own distinct forms of sanitary organizations and its own ways of combating cholera epidemics. At the same time, historical comparative analysis makes it possible to pick out patterns of relationship between illness and society within these differentiated contexts. Despite their differences, in various national communities the ethical values, beliefs, and behavior patterns that social classes, the medical profession, religious groups, and government administrations have displayed towards cholera reveal certain practically invariable symbolic patterns. Comparative analysis' made it possible, for example, to detect that in the mid-nineteenth century everyone in Rio de Janeiro as well as in New York saw cholera as a punishment from God, a disease which struck first at those whose social behavior was "censurable". There is a twofold purpose in this article's narration of the human tragedy of the New York experience with cholera: (1) to show how a sociology of evereyday life can reveal complex interactions between illness, individual, and society in a nineteenth-century metropolis and (2) to show how the analysis of a different historical experience - in this case, the United States - can uncover strong contrasts and similarities with Brazil. Such knowledge of another reality is a challenge in learning how the Brazilian population has faced this epidemic disease. In terms of the disease's macrohistorical effects, rising death rates had a less brutal impact than social and psychological factors, that is, the terror sparked by cholera within the day-to-day lives of families. From an epidemiological viewpoint, the article tells how these epidemics were products of a major breakdown in the 
balance between microparasite and human host in Asia, a breakdow that can be traced to intensified population migration prompted by European imperialism. Starting out from India, these-epidemic waves swept swiftly across Europe and the Americas, affecting above all poor populations and those residing in unhealthy areas. This is the general picture discussed in the present article, in which historical sociology borrows some of William McNeill's more enlightening analyses in historical epidemiology.

\section{RÉSUMÉ}

\section{Un Siècle de Choléra: Itinéraire de la Peur}

La méthode comparative est l'un des outils de travail essentiels de la sociologie historique. En concentrant l'attention sur un siècle d'épidémies de choléra dans quelques pays, on s'est attaché ici à démontrer comment l'étude comparée d'un même phénomène historique-social révèle des constrastes marqués selon les endroits et les époques, en matière d'impact sur la culture, la société et la politique. Par exemple, les divers processus de formation de l'État National ont marqué profondément la nature des appareils administratifs dans divers pays, entrainant chaque nation à organiser des services sanitaires différenciés et des modes différents de combat' contre les épidémies de choléra. D'un autre côte, l'analyse historique comparée permet d'entrevoir à l'intérieur de scénarios différenciés, quelques modèles constants dans la relation entre maladie et société. Malgré les différences qui ont affecté dans diverses communautés nationales, les valeurs éthiques, les croyances et les comportements des classes sociales, des professionnels de la médecine, des groupes religieux et des gouvernements face au choléra, il y a eu l'analyse comparative a permis de détecter par exemple qu'aussi bien à Rio de Janeiro qu'a New York au milieu du siècle passé, le choléra était considéré par tout le monde comme une punition divine, qui frappait en premier lieu les personnes dont le comportement social n'était pas “irréprochable”. Dans cet article, le récit de la tragédie humaine provoquée par le choléra à New York a deux buts: celui de révéler comment une sociologie du quotidien peut montrer la relation complexe entre maladie, individu et société dans une métropole du 19è siècle; et comment l'analyse d'une autre expérience historique - nord américaine - , permet de découvrir de grandes différences et similitudes avec le Brésil, la connaissance d'une autre réalité devenant ainsi un défi 
pour découvrir comment les populations brésiliennes ont affronté la maladie épidémique. Sur le plan des effets macro-historiques du choléra, l'augmentation des niveaux de mortalité a été bien moins brutale que son impact social et psychologique - la terreur provoquée par le choléra dans la vie quotidienne des familles. Du point de vue épidémiologique, cet article montre que les épidémies ont été engendrées en Asie par une grande rupture de l'équilibre entre microparasite et hôte humain — rupture elle-même due aux mouvements de populations intensifiés par l'impérialisme européen. Partant de l'Inde, les vagues épidémique se sont propagées rapidement en Europe et aux Amériques où elles ont atteint surtout les populations appauvries et habitant des zônes insalubres. Tel est le cadre général de discussion de cet article, où la sociologie historique emprunte à l'épidémiologie historique de William Mc Neill quelques unes de ses analyses les plus éclairantes. 